DOI: https://doi.org/10.24127/ajpm.v10i2.2986

\title{
KEMAMPUAN PEMAHAMAN KONSEP PADA PEMBELAJARAN MATEMATIKA BERORIENTASI REACT DAN STEM
}

\author{
Elfi Rahmadhani ${ }^{1 *}$, Septia Wahyuni ${ }^{2}$, Lola Mandasari ${ }^{3}$ \\ ${ }^{1 *, 2,3}$ IAIN Takengon, Aceh Tengah, Indonesia \\ ${ }^{*}$ Corresponding author. \\ E-mail: $\quad$ elfirahmadhani88@gmail.com ${ }^{\left.{ }^{*}\right)}$ \\ septiawahyuni86@gmail.com ${ }^{2}$ ) \\ lolamandasari@gmail.com $^{3)}$
}

Received 23 July 2020; Received in revised form 14 June 2021; Accepted 28 June 2021

\begin{abstract}
Abstrak
Penelitian ini merupakan penelitian pengembangan dengan tujuan mengembangkan perangkat pembelajaran matematika berorientasi Relating, Experienting, Applaying, Cooperating, and Transferring (REACT) dan Science, Technology, Engineering, and Mathematics (STEM) untuk melihat kemampuan pemahaman konsep siswa. Perangkat yang dikembangkan berupa RPP, LKS, dan Modul. Model pengembangan yang digunakan mengacu kepada model pengembangan ADDIE (Analysis, Design, Development, Implementation and Evaluation). Materi yang digunakan pada perangkat pembelajaran yang dikembangkan adalah materi Bangun Datar dengan subjek penelitian adalah siswa kelas VII SMP N 1 Takengon yang terdiri dari 28 siswa. Instrument yang digunakan dalam penelitian ini adalah lembar validasi RPP, LKS, Modul, tes pemahaman konsep, serta angket respon guru dan siswa terhadap perangkat yang dikembangkan. Analisis data yang digunakan adalah analisis kevalidan, kepraktisan, dan keefektifan. Hasil yang diperoleh adalah perangkat pembelajaran termasuk pada kategori valid, berdasarkan hasil validasi oleh validator ahli pendidikan matematika, ahli model pembelajaran dan ahli media pembelajaran. Perangkat tersebut dikategorikan praktis untuk digunakan berdasarkan 1) hasil observasi kemampuan guru dalam melaksanakan proses pembelajaran dengan menggunakan perangkat pembelajaran yang dikembangkan tergolong baik, 2) respon guru terhadap perangkat tersebut sangat baik, dan 3) respon siswa sangat baik terhadap perangkat tersebut. Perangkat pembelajaran berorientasi REACT dan STEM juga efektif digunakan untuk melihat kemampuan pemahaman konsep siswa yang menunjukkan bahwa rata-rata skor siswa lebih dari KKM dari sekolah, yaitu 83,60 > 70 .
\end{abstract}

Kata kunci: Pemahaman konsep; perangkat pembelajaran; REACT; STEM.

\begin{abstract}
This research is a development research with the aim to develop the learning of mathematics oriented Relating, Experienting, Applaying, Cooperating, and Transferring (REACT) dan Science, Technology, Engineering, and Mathematics (STEM) to see the understanding of mathematical concepts of students. The learning tools developed are lesson plans, strudent worksheets and sudent books. The development model used is ADDIE (Analysis, Design, Development, Implementation and Evaluation). The material used in the learning device developed is the Bangun Datar material with the research subject being class VII students of SMP N 1 Takengon which consists of 28 students. The instruments used in this study were RPP validation sheets, worksheets, modules, concept understanding tests, and teacher and student response questionnaires to the developed tools. Analysis of the data used is the analysis of validity, practicality, and effectiveness. The results obtained are learning tools are included in the valid category, based on the results of validation by validators of mathematics education experts, learning model experts and learning media experts. The device is categorized as practical to use based on 1) the results of observations of the teacher's ability to carry out the learning process using the learning tools developed are classified as good, 2) the teacher's response to the device is very good, and 3) the student response is very good to the device. REACT and STEM oriented learning tools are also effectively used to see students' conceptual understanding abilities which show that the average score of students is more than the KKM set by the school, which is $83.60>70$.
\end{abstract}

Keywords: REACT strategy; STEM; and the understanding of mathematical concept.

This is an open access article under the Creative Commons Attribution 4.0 International License 
DOI: https://doi.org/10.24127/ajpm.v10i2.2986

\section{PENDAHULUAN}

Pemahaman merupakan suatu kemampuan untuk menangkap makna dan arti dari bahan yang dipelajari, seperti menafsirkan, menjelaskan atau meringkas sesuatu. Pemahaman konsep merupakan kunci dari suatu pembelajaran, karena tujuan utama dari pembelajaran adalah membuat siswa memahmai konsep yang diberikan. Hal ini sesuai dengan pendapat Lestari, Lestari, \& Ridha (2018) yang mengatakan bahwa dalam proses pembelajaran seharusnya lebih menekankan kepada penguasaan konsep pembelajaran agar siswa mempunyai dasar dalam memecahkan setiap masalah yang diberikan, tidak hanya mempelajari angka dan rumus saja. Pemahaman konsep akan berkembang jika guru dapat mengeksplorasi topik pembelajaran secara mendalam dan memberi mereka contoh yang tepat, menarik dan berhubungan dengan kehidupan mereka sehari-hari. Menurut Kamarullah (2017), guru dituntut untuk mengarahkan tujuan pembelajaran kearah yang sesuai dengan tuntutan kurikulum seperti: 1) memahami konsep yang ada pada matematika, kemudian menjelaskan hubungan antar konsep dan mengaplikasikannya dalam pemecahan masalah, 2) melakukan penalaran, manipulasi, menyusun bukti dan memberikan penjelasan dari gagasan, ide dan pernyataan matematika, 3) meyelesaikan atau memecahkan masalah yang diberikan dengan memahami masalah terlebih dahulu, kemudian merancang model matematika dari masalah yang diberikan, menyelesaikan model dan menafsirkan solusi dari masalah tersebut, 4) menyajikan ide dan gagasan dari pemecahan masalah dengan menggunakan simbol, grafik, tabel atau diagram, serta 5) menghargai manfaat matematika dalam kehidupan seharihari.

Menurut Wardhani (2010) pemahaman siswa terhadap konsep yang diberikan dapat dilihat dari beberapa indikator, seperti: 1) menyatakan ulang konsep, 2) mengidentifikasi dan membuat contoh dan bukan contoh dari suatu konsep yang diberikan, 3) menggunakan model, diagram, dan simbol untuk merepresentasikan suatu konsep, 4) mengubah suatu bentuk representasi ke bentuk lainnya, 5) mengaplikasikan konsep atau algoritma dalam pemecahan masalah, 6) mengidentifikasi sifat-sifat suatu konsep dan mengenal syarat perlu atau syarat cukup dari suatu konsep serta 7) mengaitkan konsep dengan konsep lainnya.

Berdasarkan observasi yang dilakukan di beberapa SMP di Takengon, diketahui bahwa kemampuan pemahaman konsep siswa masih tergolong rendah. Hal ini dibuktikan dari hasil studi pendahuluan yang telah dilakukan. Dari 4 soal yang diberikan kepada siswa, rata-rata siswa yang dapat menyelesaikannya hanya $53,68 \%$. Hal ini dapat mengakibatkan rendahnya hasil belajar siswa. Karena jika siswa tidak memahami konsep yang diberikan dengan baik, maka mereka akan kesulitan dalam menyelesaikan setiap masalah yang diberikan.

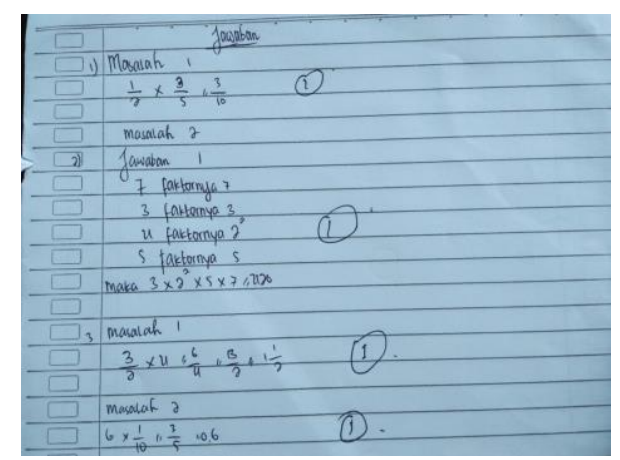

Gambar 1. Jawaban siswa 
Pentingnya pemahaman konsep ini dapat dilihat dari banyaknya usaha dan kiat yang dilakukan oleh guru dalam menyampaikan materi pelajaran agar siswa mudah memahaminya. Selain itu, banyak penelitian yang telah dilakukan untuk mengembangkan dan meningkatkan pemahaman konsep siswa, diantaranya adalah penelitian yang dilakukan oleh Rahmadhani (2016), Romadon \& Mahmudi (2019), Jannah, Supriadi, \& Suri (2019), Wijaya, Yunarti, \& Ludinsyah (2019) dan Prihatiningtyas \& Mariyam (2019). Dalam penelitian Rahmadhani (2016) mengatakan bahwa salah satu strategi yang dapat meningkatkan kemampuan pemahaman konsep siswa adalah strategi REACT.

Menurut Rahmadhani (2017), strategi REACT merupakan salah satu strategi yang dapat menciptakan pembelajaran matematika yang lebih bermakna, karena mengaitkan materi pembelajaran dengan dunia nyata siswa. Hal ini didukung oleh pendapat Crawford (dalam Rahmadhani, 2016), yang mengatakan bahwa strategi REACT merupakan suatu strategi pembelajaran yang cocok untuk menciptakan pembelajaran yang lebih bermakna, dimana strategi ini terdiri dari lima aspek, yaitu 1) Relating, lebih menekankan kepada pengalaman hidup/belajar, siswa mampu menghubungkan pengetahuan yang dimiliki dengan kehidupan sehari-hari. 2) Experienting, siswa membangun dan menemukan pengetahuan sendiri, dengan terlibat secara aktif dalam proses penemuan konsep. 3) Applaying, siswa menggunakan konsep yang telah mereka dapatkan dengan menyelesaikan masalah yang diberikan. 4) Cooperating, siswa saling bertukar pikiran dan diskusi dalam menemukan konsep yang diberikan dan 5)
Transferring, mengembangkan pengetahuan atau menggunakan pengetahuan yang telah diperoleh pada konteks permasalahan baru.

Berdasarkan hasil penelitian Rahmadhani (2016), diketahui bahwa penggunaan strategi REACT dalam pembelajaran dapat meningkatkan kemampuan pemahaman konsep siswa, baik siswa dengan kemampuan awal tinggi, sedang maupun rendah. Hal ini terjadi karena strategi REACT tidak hanya menuntut siswa menemukan konsep saja dalam pembelajaran, tetapi juga dituntut untuk dapat menghubungkan konsep ke dunia nyata mereka. Sejalan dengan pendapat Nugroho, Prayitno, \& Maridi (2017) yang mengatakan bahwa beberapa keunggulan dari strategi REACT dalam pembelajaran adalah 1) mampu membantu mendorong siswa menghubungkan pengetahuan yang telah mereka miliki dengan kehidupan sehari-hari sehingga dapat meningkatkan pemahaman meeka terhadap materi, 2) mampu membantu meningkatkan aktivitas siswa dalam pembelajaran melalui kegiatan kelompok, dan 3) mampu membantu siswa meningkatkan kemampuannya dalam mentransfer materi yang telah mereka miliki ke dalam masalah yang lebih kompleks.

Selain menggunakan strategi REACT, untuk melihat dan meningkatkan kemampuan pemahaman konsep siswa, pembelajaran juga dapat disajikan dengan mengintegrasikan STEM dalam prosesnya. Rahmadhani \& Wahyuni (2018) dalam penelitiannya menyimpulkan bahwa kemampuan pemahaman konsep dan minat mahasiswa mengalami peningkatan setelah menerima pembelajaran yang menggunakan STEM dalam prosesnya baik untuk siswa dengan kemampuan 
tinggi, sedang dan rendah. Dalam penelitiannya Rahmadhani menggunakan alat bantu atau media macromedia flash sebagai bentuk teknologi yang digunakan dalam membantu dosen menyampaikan materi pelajaran.

STEM merupakan suatu disiplin ilmu yang berkaitan erat satu dan lainnya. Sesuai dengan pendapat Nessa, Hartono, \& Hiltrimartin (2017), Science, Technology, Engineering, and Mathematics (STEM) merupakan salah satu pendekatan yang terbentuk dari beberapa disiplin ilmu seperti Sains, Teknologi, Teknik dan Matematika. Di era globalisasi saat ini, menggunakan STEM dalam pembelajaan sangat perlu. Bahkan menurut Permanasari (2016), beberapa negara maju seperti Amerika dan Jepang pada saat sekarang ini kembali menggunakan pembelajaran yang dapat membantu siswa menguasai pembelajaran dengan cara mendekatkan dan mengaplikasikan materi pelajaran dengan kehidupan mereka sehari-hari, salah satunya dengan menggunakan STEM, STES dan CTL. Banyak penelitian yang telah dilakukan terkait dengan STEM yang diaplikasikan dalam pembelajaran, diantaranya adalah penelitian oleh Afriana, Permanasari, \& Fitriani (2016). Dalam penelitiannya diketahui bahwa hampir seluruh siswa menyatakan senang dengan pembelajaran menggunakan STEM, dimana mereka memperoleh pengalaman yang sangat berkesan yang dapat menumbuhkan motivasi dan meningkatkan hasil belajar mereka. Selain itu Septiani (2016) juga menambahkan bahwa STEM dalam pembelajaran mampu melatih siswa secara kognitif, keterampilan dan afektif, dimana siswa tidak hanya diajarkan teori tetapi juga praktik. Menurut National Research Council
(2011), dalam proses pembelajaran menggunakan STEM ada beberapa aspek yang perlu ditekankan, seperti: 1) mengajukan pertanyaan (science) dan mendefinisikan masalah (engineering), 2) mengembangkan dan menggunakan model, 3) merencanakan dan melakukan investigasi, 4) melakukan analisis dan tafsiran data (mathematis), 5) menggunakan matematika; teknologi informasi dan komputer; berpikir komputasi (technology), 6) membangun eksplanasi (science) dan merancang solusi (engineering), 7) terlibat dalam argument berdasarkan bukti serta 8) memperoleh, mengevaluasi dan mengkomunikasikan informasi. Hal ini sejalan dengan tujuan Kurikulum 2013 yang menuntut guru untuk dapat mengenalkan skill tenaga kerja agar dapat mempersiapkan siswa menghadapi abad 21.

Selain dalam Rencana Pelaksanaan Pembelajaran (RPP), STEM juga dapat diadaptasikan pada bahan ajar, media atau perangkat pembelajaran lainnya, seperti penelitian yang dilakukan oleh Nessa et al., (2017). Dalam penelitiannya Nessa et al. (2017) mengembangkan modul berbasis STEM yang tergolong valid, dan praktis. Berdasarkan hasil pengolahan data terbukti bahwa modul yang dikembangkan efektif terhadap hasil belajar siswa, dan terlihat siswa antusias dalam proses pembelajaran menggunakan modul tersebut, dimana mereka mengatakan bahwa mereka dapat memahami materi yang diberikan dengan baik karena bahasa yang digunakan mudah dipahami dan materi yang disajikan dikaitkan dengan kehidupan mereka kesehariannya.

Melihat penjelasan di atas, maka tujuan penelitian ini adalah untuk mengembangkan suatu perangkat pembelajaran yang berorientasi pada 
REACT dan STEM. Hal ini dirasa sangat efektif untuk meningkatkan pemahaman konsep siswa dalam pembelajaran matematika, karena perangkat yang dikembangkan mengintegrasikan tahapan REACT dan karakteristik STEM di dalamnya. Salah satu perangkat yang dikembangkan adalah media pembelajaran berupa Lembar Kerja Siswa (LKS) dan Modul. Penggunaan media pembelajaran berupa LKS dan modul dalam pembelajaran dapat membuat proses pembelajaran berlangsung dengan lebih tepat guna dan berdaya guna sehingga tujuan pembelajaran dapat tercapai dengan baik (Purbasari, Kahfi, \& Yunus, 2013). Menurut Kusumaningsih, Sutrisno, \& Hidayah (2019), LKS dan modul merupakan salah satu media atau perangkat pembelajaran yang dapat membantu guru dalam melaksanakan proses pembelajaran. Selain itu, LKS dan modul dalam pembelajaran berperan dalam membantu siswa merekonstruksi pengetahuan yang akan mereka pelajari melalui kegiatan diskusi kelompok. Seperti penelitian yang dilakukan oleh Utami \& Jatmiko (2018) dengan mengembangkan modul pembelajaran matematika menggunakan pendekatan STEM. Menurut mereka, kelebihan modul pembelajaran yang mereka kembangkan adalah menjadi penuntun untuk belajar mandiri bagi siswa yang dilengkapi dengan lab-mini matematika dan ilustrasi-ilustrasi konsep materi yang membantu mereka dalam memahami materi yang diberikan.

\section{METODE PENELITIAN}

Penelitian ini merupakan penelitian pengembangan dengan tujuan untuk mengembangkan perangkat pembelajaran berupa RPP, LKS dan Modul yang berorientasi REACT dan
STEM untuk melihat kemampuan pemahaman konsep siswa pada materi Bangun Datar di kelas VII SMP. Model pengembangan yang digunakan adalah model pengembangan ADDIE (Analysis, Design, Development, Implementation and Evaluation). Dengan rincian, yaitu 1) Analysis. Pada tahap ini dilakukan analisis kebutuhan, karakter siswa dan analisis buku paket yang digunakan di sekolah. Hal ini dilakukan untuk mendapatkan informasi yang berkaitan dengan perangkat yang akan dikembangkan. 2) Design. Pada tahap ini, dirancang prototype perangkat pembelajaran matematika berupa RPP, LKS dan Modul yang berorientasi REACT dan STEM. Pada tahap ini juga disusun tes untuk melihat kemampuan pemahaman konsep siswa, serta angket untuk melihat bagaimana respon guru dan siswa terhadap perangkat pembelajaran matematika yang dikembangkan. 3) Development. Pada tahap ini, dihasilkan prototype perangkat pembelajaran matematika berupa RPP, LKS dan Modul berorientasi REACT dan STEM. Perangkat ini kemudian divalidasi oleh 3 orang ahli, yaitu ahli pendidikan matematika, ahli model pembelajaran dan ahli media pembelajaran. Berdasarkan hasil validasi ahli, maka dilakukan revisi terhadap produk yang dikembangkan. 4) Implementation. Pada tahap ini, perangkat pembelajaran matematika yang telah valid kemudian diujicobakan pada sampel kecil untuk melihat kepraktisan dan keefektifan perangkat yang dikembangkan. 5) Evaluation. Pada tahap terakhir dilakukan evaluasi kualitas produk berdasarkan validitas produk, uji kepraktisan produk, dan uji efektifitas produk. Revisi terakhir menghasilkan perangkat pembelajaran matematika yang layak pakai. 
RPP berorientasi REACT dan STEM yang dikembangkan memuat komponen pokok suatu RPP seharusnya sesuai dengan Permendiknas Nomor 63 tahun 2013, yakni: a) memuat identitas mata pelajaran, b), memuat kompetensi inti, c), memuat kompetensi dasar, d), memuat indikator pencapaian kompetensi, e) memuat tujuan pembelajaran, f) memuat materi ajar, g) memuat alokasi waktu, h) memuat metode pembelajaran yaitu strategi REACT dan STEM, i) memuat media/alat bantu belajar seperti LKS dan modul pembelajaran, j) memuat kegiatan pembelajaran yang mengikuti langkah-langkah pembelajaran dengan strategi REACT yaitu Relating, Experienting, Applaying, Cooperating, dan 5) Transferring. Serta karakteristik STEM yaitu Science, Technology, Engineering, and Mathematics. k) memuat penilaian, baik penilaian proses maupun penilaian akhir, dan 1) sumber belajar.

Dalam merancang Lembar Kerja Siswa (LKS) berorientasi REACT dan STEM, ada beberapa hal yang harus diperhatikan yaitu: a) Identitas dari siswa dan judul LKS, b) Petunjuk siswa mengenai topik yang dibahas, pengarahan umum dan waktu yang tersedia untuk menyelesaikannya, c) Tujuan pelajaran yang diharapkan diperoleh oleh siswa setelah mereka belajar dengan LKS tersebut. Pada bagian ini diintegrasikan tahapan REACT seperti Relating dan Experienting. d) Alat-alat pelajaran yang digunakan, dan e) Petunjukpetunjuk khusus tentang langkahlangkah kegiatan yang ditempuh oleh siswa dan diberikan secara terperinci serta diselingi dengan pelaksanaan kegiatan. Pada langkah-langkah pembelajaran dicantumkan bahwa kegiatan tersebut merupakan bagian dari tahapan REACT yaitu Applaying dan Cooperating.

Sedangkan dalam merancang modul pembelajaran, dilakukan beberapa langkah berikut ini, yaitu: 1) menuliskan identitas dari modul yang dikembangkan, seperti judul modul, jumlah jam pelajaran dan prasyarat. 2) menuliskan petunjuk pengerjaan modul, seperti penjelasan bagaimana mempelajari atau mengerjakan modul tersebut. 3) menuliskan tujuan pembelajaran, seperti sasaran atau hasil yang diharapkan dicapai dengan pembelajaran menggunakan modul tersebut. Tujuan ini berisi rumusan tentang tujuan pembelajaran khusus. 4) menuliskan bahan bacaan. Berisi pengetahuan tentang konsep, prinsip, kaidah, metode, modul, prosedur dll yang diharapkan dikuasai oleh siswa. Bahan disusun secara sistematis, sekuensial, memperhatikan prinsipprinsip dan langkah-langkah strategi REACT dan STEM, mudah-sukar, konkrit-abstrak, logis-psikologis, lingkup-konstruk dsb. Materi pembelajaran disajikan dengan mengaitkan setiap konsep dengan kondisi nyata yang sering terjadi di lingkungan sekitar siswa serta dikaitkan dengan bidang kajian lainnya yang mendukung pemahaman siswa terhadap materi yang disajikan. Bahan bacaan untuk satuan topik biasanya cukup luas, mencakup beberapa subpokok bahasan. Tiap subpokok bahasan dijadikan satu kegiatan pembelajaran. 5) menuliskan kegiatan belajar-mengajar, dengan menekankan siswa belajar aktif. Di samping membaca teks, siswa dituntut melakukan tugas-tugas dan latihan tertentu, seperti menjawab pertanyaan, melakukan pengamatan, percobaan, membuat rencana, menghitung, memecahkan masalah, mengumpulkan data dari dokumen atau lapangan, dll. 
Modul ini didesain agar mudah dipahami oleh siswa, sehingga mereka dapat belajar sendiri tanpa harus menunggu bantuan dari guru.6) menuliskan media dan sumber pelajaran yang mendukung. Materi dan kegiatan dalam modul menuntut siswa agar menggunakan media dan sumber pembelajaran, seperti laptop, HP, kalkulator, serta situs web. 7) menuliskan tes atau latihan soal yang diguakan untuk mengukur tingkat pemahaman siswa terhadap materi pada modul yang telah mereka pelajari. Pada setiap akhir pelajaran dan akhir modul disediakan tes, biasanya berbentuk tes objektif. Untuk tes akhir kegiatan tes dan kunci jawaban disajikan pada modul dan dapat diperiksa sendiri oleh siswa.

Subjek dalam penelitian ini merupakan siswa kelas VII SMP N 1 Takengon yang terdiri dari 28 siswa. Materi yang digunakan pada pengembangan perangkat pembelajaran ini adalah materi Bangun Datar. Instrumen yang digunakan dalam penelitian ini adalah lembar validasi perangkat pembelajaran matematika (RPP, LKS dan Modul), soal tes untuk melihat kemampuan pemahaman konsep dengan jumlah soal adalah 5 soal uraian serta angket untuk melihat respon guru sebanyak 17 pernyataan dan angket respon siswa terhadap perangkat pembelajaran matematika yang dikembangkan sebanyak 15 pernyataan. Indikator yang digunakan untuk melihat kemampuan pemahaman konsep siswa adalah 1) menyatakan ulang konsep, 2) mengidentifikasi dan membuat contoh dan bukan contoh dari suatu konsep yang diberikan, 3) menggunakan model, diagram, dan simbol untuk merepresentasikan suatu konsep, 4) mengubah suatu bentuk representasi ke bentuk lainnya, 5) mengaplikasikan konsep atau algoritma dalam pemecahan masalah, 6) mengidentifikasi sifat-sifat suatu konsep dan mengenal syarat perlu atau syarat cukup dari suatu konsep serta 7) mengaitkan konsep dengan konsep lainnya.

Analisis data yang dilakukan dalam penelitian ini adalah analisis kevalidan, keefektifan dan kepraktisan yaitu: 1) Analisis validasi perangkat pembelajaran matematika dari validator berupa RPP, LKS, Modul, tes dan angket. 2) Analisis tes kemampuan pemahaman konsep siswa. 3) Analisis angket respon guru dan siswa terhadap perangkat pembelajaran yang dikembangkan.

\section{HASIL DAN PEMBAHASAN}

Prototipe Perangkat Pembelajaran Penelitian ini menghasilkan perangkat pembelajaran yang berorientasi REACT dan STEM pada materi Bangun Datar berupa RPP, LKS, dan Modul. Perangkat dikembangkan berdasarkan tahapan dan karakteristik dari REACT dan STEM.

a. RPP disusun berdasarkan tahapan pada strategi REACT dan aspek atau karakteristik STEM, yaitu 1) Relating, pada tahap ini guru menumbuhkan hasrat belajar siswa dengan mengaitkan materi dengan kehidupan sehari-hari dan dengan pengetahuan yang telah dimiliki oleh siswa sebelumnya. Seperti: "pernahkah kamu memperhatikan susunan kue yang ada pada rak di supermarket? Menurut pendapatmu berbentuk seperti apa sajakah kotakkotak kue tersebut?". 2) Experienting, pada tahap ini siswa berdiskusi dalam kelompok untuk menemukan konsep materi bangun datar. Selain itu siswa juga mengajukan pertanyaan (science), 
DOI: https://doi.org/10.24127/ajpm.v10i2.2986

merencanakan dan melakukan investigasi serta mendefinisikan masalah untuk menemukan konsep (engineering), 3) Applaying, siswa mengerjakan soal yang ada pada LKS dengan melakukan analisis dan tafsiran data (mathematic, technology), dan merancang solusi dari masalah yang diberikan (engineering), 4) Cooperating, siswa saling bertukar pikiran dan diskusi dalam menemukan konsep yang diberikan serta 5) Transferring, pada tahap terakhir ini siswa menjawab pertanyaan guru mengenai konsep dasar dalam bangun datar.

b. LKS dan Modul disusun berdasarkan karakteristik dari strategi REACT dan STEM. LKS terdiri dari langkah-langkah penemuan konsep yang disusun dengan mengaitkan materi dengan lingkungan sehari-hari siswa. Untuk mengenalkan bentuk-bentuk bangun datar kepada siswa, mereka diminta untuk membawa dan menyebutkan benda-benda yang ada disekitar mereka yang menyerupai bangun datar yang akan mereka pelajari. Kemudian mereka diminta untuk menghitung panjang, lebar, keliling dan luas dari benda yang mereka sebutkan dan bawa tadi. LKS disusun untuk dapat dikerjakan secara berkelompok dengan melakukan investigasi dan analisis bersama sebelum menemukan konsep yang akan dipelajari. Soalsoal yang disediakan dalam LKS merupakan soal yang dapat menumbuhkan dan meningkatkan kemampuan pemahaman konsep siswa. Sedangkan modul yang dikembangkan berisikan materi yang harus mereka pelajari tentang Bangun Datar. Materi tersebut disajikan dengan menarik dan jelas, sehingga siswa mudah memahami materi yang dipelajarinya dengan sendiri tanpa bantuan guru. Perangkat yang dikembangkan dapat dilihat pada Gambar 2 dan Gambar 3.

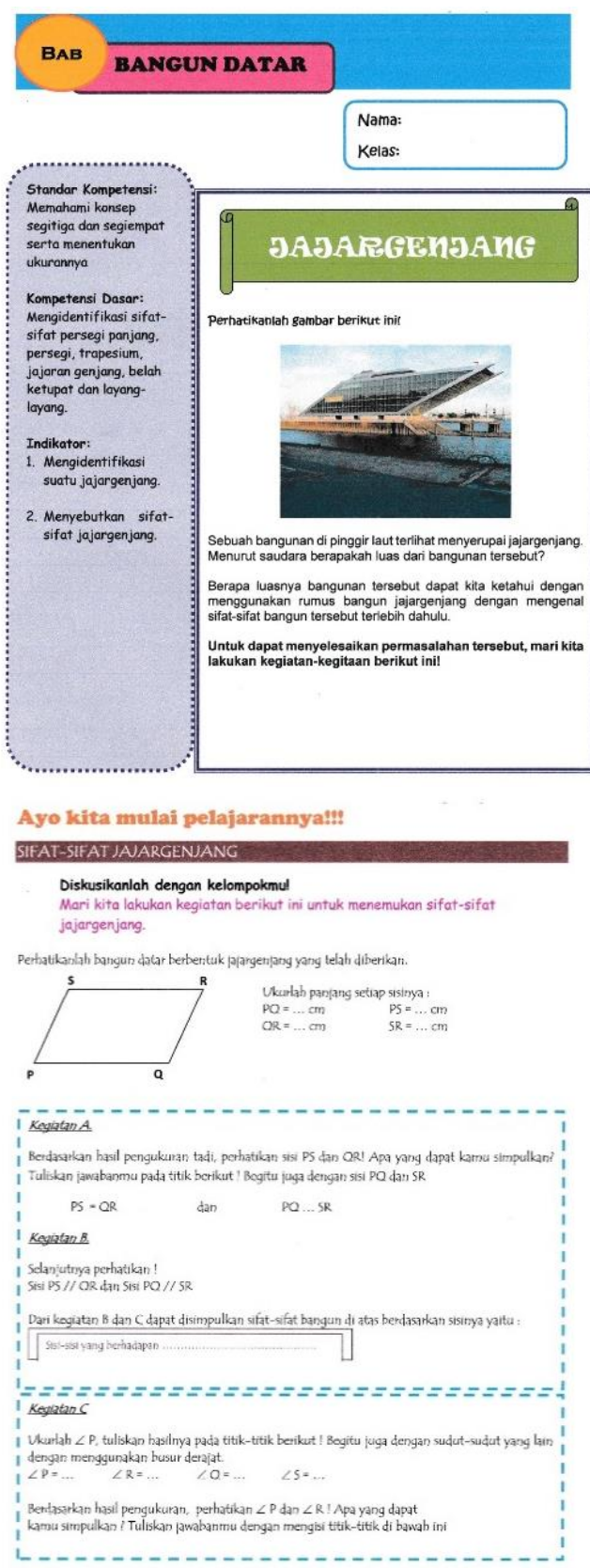

Gambar 2. Contoh LKS 
DOI: https://doi.org/10.24127/ajpm.v10i2.2986

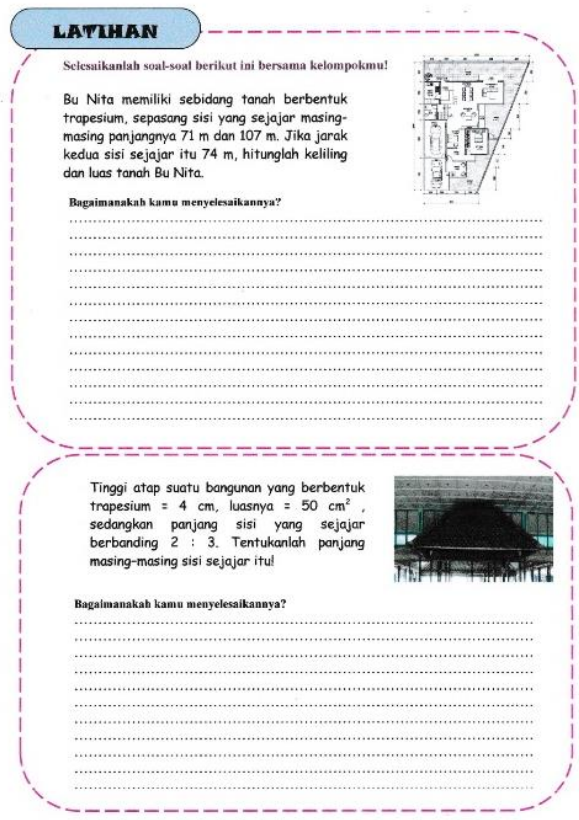

Gambar 3. Contoh soal latihan

\section{Validasi Perangkat Pembelajaran}

Prototipe perangkat pembelajaran yang telah dikembangkan kemudian divalidasi oleh 3 orang ahli, yaitu ahli matematika, ahli metode pembelajaran dan ahli media pembelajaran. Ahli materi memberikan penilaian terhadap komponen materi pembelajaran yang dikembangkan, isi materi disesuaikan dengan SK dan KD. Ahli metode pembelajaran memberikan penilaian terhadap komponen pengintegrasian strategi REACT dan STEM dalam perangkat yang dikembangkan, sedangkan ahli media pembelajaran memberikan penilaian terhadap perangkat mulai dari kelayakan bahasa, kegrafikan, dan kesesuaian perangkat yang dikembangkan dengan karakter dan usia siswa. Menurut Hobri (2010), skor penilaian dari setiap validator dihitung dengan membagi rata-rata jumlah skor perangkat pembelajaran dengan banyaknya aspek penilaian perangkat pembelajaran. Perangkat pembelajaran yang dikembangkan dikatakan valid jika mendapat kategori baik dan sangat baik. Hasil rekapitulasi dari validator tersebut dapat dilihat pada Tabel 1.

Tabel 1. Hasil rekapitulasi validasi prototipe perangkat pembelajaran

\begin{tabular}{clccccc}
\hline \multirow{2}{*}{ No. } & \multirow{2}{*}{ Perangkat } & \multicolumn{3}{c}{ Validator } & \multirow{2}{*}{ Rata-rata } & \multirow{2}{*}{ Kategori } \\
\cline { 3 - 5 } & & $\mathbf{1}$ & $\mathbf{2}$ & $\mathbf{3}$ & & \\
\hline 1 & RPP & 80,62 & 77,5 & 81,87 & 79,99 & Valid \\
\hline 2 & LKS & 76,47 & 80 & 78,82 & 78,43 & Valid \\
\hline 3 & Modul & 77,87 & 81 & 79,21 & 79,36 & Valid \\
\hline 5 & Angket Respon Guru & 80 & 77,65 & 81,17 & 79,61 & Valid \\
\hline 6 & Angket Respon Siswa & 77,33 & 81,33 & 73,33 & 77,33 & Valid \\
\hline
\end{tabular}

Berdasarkan Tabel 1 diketahui bahwa perangkat pembelajaran yang dikembangkan dapat dikategorikan valid dan kemudian dilakukan perbaikan sesuai dengan saran dari semua validator. Dari segi komponen materi pembelajaran yang dikembangkan, isi materi telah sesuai dengan SK dan KD yang terdapat pada kurikulum 2013. Sedangan dari segi Bahasa, perangkat pembelajaran yang dikembangkan memiliki Bahasa yang telah sesuai dengan EYD, komunikatif dan mudah dipahami oleh siswa karena sesuai dengan karakter dan usia mereka. Setelah validasi terdapat beberapa perubahan pada perangkat yang dikembangkan, salah satunya pada LKS. Sebelum validasi tidak terdapat TTS dan lembar diskusi siswa sebagai selingan untuk menjaga konsentrasi dan ketertarikan siswa terhadap materi yang diberikan. Berdasarkan saran dari validator, maka disusunlah suatu TTS 
DOI: https://doi.org/10.24127/ajpm.v10i2.2986

tentang bangun datar dan lembar diskusi siswa seperti terlihat pada Gambar 4 dan Gambar 5.
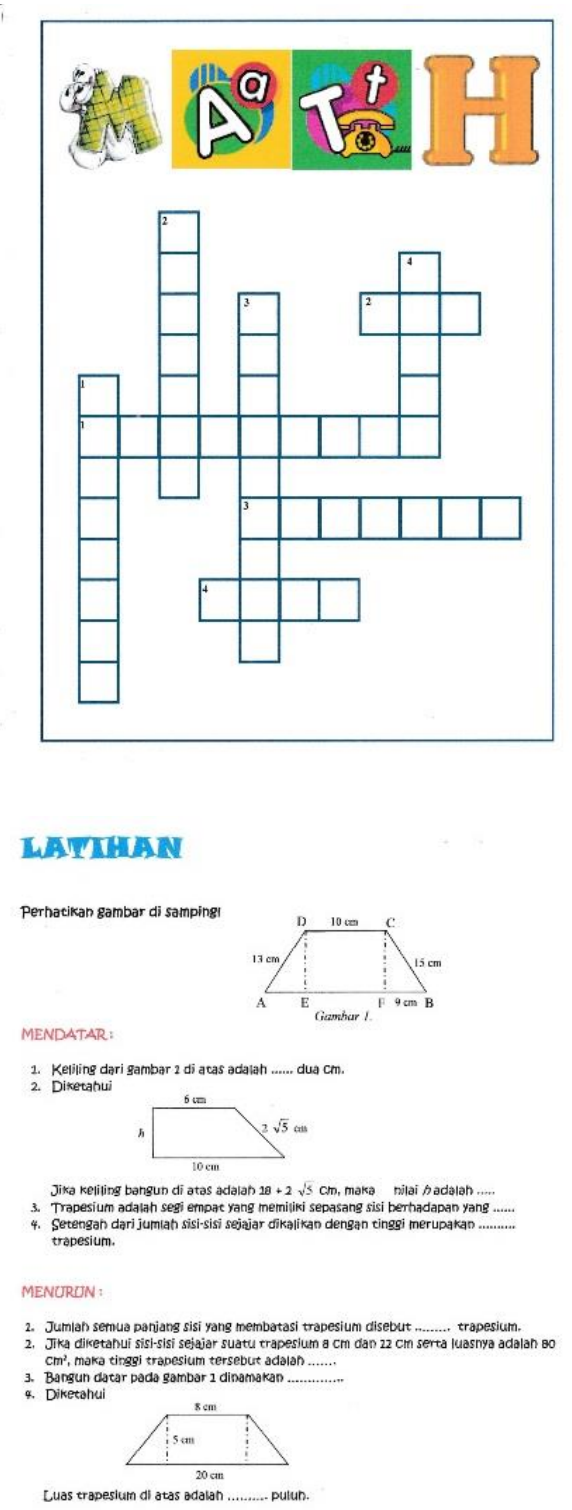

Gambar 4. Contoh TTS

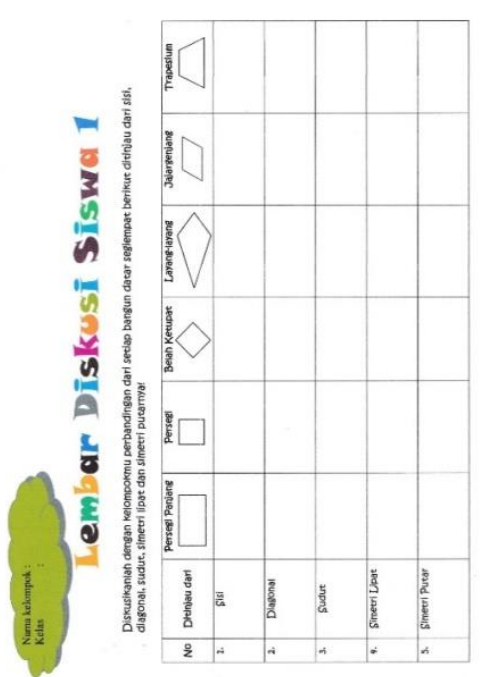

Gambar 5. Lembar diskusi siswa

Untuk tes kemampuan pemahaman konsep, dari hasil validasi ketiga validator dapat disimpulkan bahwa 5 soal tes uraian yang dikembangkan dapat digunakan dengan revisi kecil. Untuk mengetahui validitas empirisnya, maka dilakukan uji coba tes untuk melihat validitas, reliabilitas, daya pembeda, dan indeks kesukaran soal yang dikembangkan. Berdasarkan hasil pengolahan data hasil validasi empiris tes kemampuan pemahaman konsep, diketahui bahwa semua soal yang diujicobakan dapat dipakai dengan reliabilitas soal berada pada kategori tinggi yaitu sebesar 0,66. Sedangkan daya pembeda soal rata-rata berada pada kategori cukup dan indeks pembeda soal berada pada kategori mudah. Hasil pengolahan data tersebut dapat dilihat pada Tabel 2.

Tabel 2. Hasil validasi empiris tes kemampuan pemahaman konsep

\begin{tabular}{|c|c|c|c|c|c|c|c|c|c|c|}
\hline $\begin{array}{l}\text { No. } \\
\text { soal }\end{array}$ & $\begin{array}{c}\mathbf{t} \\
\text { hitung }\end{array}$ & $\begin{array}{c}\mathrm{t} \\
\text { tabel }\end{array}$ & Ket & r11 & Ket & Dp & Ket & Ik & Ket & Klasifikasi \\
\hline 1 & 4,21 & \multirow{5}{*}{2,16} & Valid & \multirow{5}{*}{0,66} & \multirow{5}{*}{ tinggi } & 0,29 & Cukup & 0,77 & Mudah & Dipakai \\
\hline 2 & 2,84 & & Valid & & & 0,22 & Cukup & 0,90 & Mudah & Dipakai \\
\hline 3 & 3,01 & & Valid & & & 0,27 & Cukup & 0,82 & Mudah & Dipakai \\
\hline 4 & 2,59 & & Valid & & & 0,26 & Cukup & 0,75 & Mudah & Dipakai \\
\hline 5 & 2,42 & & Valid & & & 0,22 & Cukup & 0,87 & Mudah & Dipakai \\
\hline
\end{tabular}


DOI: https://doi.org/10.24127/ajpm.v10i2.2986

\section{Uji Kepraktisan Perangkat}

Pembelajaran

Setelah perangkat pembelajaran divalidasi dan dilakukan revisi 1 produk, maka langkah selanjutnya adalah melakukan uji kepraktisan terhadap perangkat yang dikembangkan. Kepraktisan perangkat diperoleh melalui uji coba terbatas yang dilakukan di SMP N 1 Takengon. Menurut Trianto (2010), suatu perangkat pembelajaran dikatakan praktis jika memenuhi kriteria: 1) kemampuan guru dalam melaksanakan proses pembelajaran dengan menggunakan perangkat pembelajaran yang dikembangkan tergolong baik, hal ini didapatkan melalui observasi, 2) respon guru dan siswa selama pembelajaran baik/positif. Data ini diperoleh melalui angket yang diberikan kepada guru dan siswa. Analisis data terhadap observasi guru dalam mengelola pembelajaran dengan menggunakan perangkat pembelajaran berorienasi REACT dan STEM dilakukan dengan cara menghitung jumlah skor setiap indikator dari observer dibagi dengan banyaknya item pernyataan. Hasil pengolahan data observasi guru dalam 4 kali pertemuan dapat dilihat pada Tabel 3 .

Tabel 3. Data observasi proses pembelajaran

\begin{tabular}{ccc} 
Pertemuan & $\begin{array}{c}\text { Rata- } \\
\text { rata }\end{array}$ & Kriteria \\
\hline 1 & 4,3 & Baik \\
2 & 4,5 & Sangat baik \\
3 & 4,6 & Sangat baik \\
4 & 4,9 & Sangat baik \\
\hline Jumlah & $\mathbf{4 , 5 7}$ & Sangat baik \\
\hline
\end{tabular}

Berdasarkan data Tabel 3 diketahui bahwa pada pertemuan pertama guru sudah mulai dapat mengaplikasikan setiap tahapan dan karakteristik dari RPP berorientasi
REACT dan STEM dengan baik di kelas. Pada pertemuan selanjutnya guru melakukan perbaikan dibeberapa tahapan pada RPP yang dikembangkan, salah satunya adalah dalam manajemen waktu. Guru sudah mulai dapat mengontrol kelas dan mengatur waktu pembelajaran sehingga tujuan yang diharapkan dapat tercapai dengan baik disetiap pertemuannya. Keterlaksanaan proses pembelajaran dengan baik, dapat membantu guru melatih kemampuan pemahaman konsep siswa, sehingga siswa dapat dengan mudah memahami konsep yang diberikan kepada mereka. Sedangkan analisis data angket respon guru dan siswa terhadap perangkat pembelajaran matematika yang dikembangkan dilakukan dengan cara menjumlahkan rata-rata aspek yang direspon dibagi dengan jumlah seluruh aspek yang direspon. Hasil pengolahan data angket guru serta siswa dapat dilihat pada tabel 4:

Tabel 4. Data angket respon guru dan siswa

\begin{tabular}{ccc}
\hline Data & Skor (\%) & Kriteria \\
\hline Respon guru & 92,5 & $\begin{array}{c}\text { Sangat } \\
\text { praktis }\end{array}$ \\
\hline Respon siswa & 87 & Sangat baik \\
\hline
\end{tabular}

Berdasarkan tabel 4 di atas, diketahui bahwa guru dan siswa menyatakan bahwa perangkat pembelajaran yang dikembangkan mudah digunakan, mudah dipahami dan instruksi yang diberikan mudah dimengerti, maka dapat disimpulkan bahwa perangkat pembelajaran yang dikembangkan tergolong praktis. Hal ini dikarenakan respon guru terhadap perangkat pembelajaran matematika berorientasi REACT dan STEM berupa RPP, LKS, dan Modul yang dikembangkan sangat praktis dan respon siswa juga sangat baik. 
DOI: https://doi.org/10.24127/ajpm.v10i2.2986

\section{Uji Keefektifan Perangkat}

Pembelajaran

Langkah selanjutnya adalah melihat efektivitas perangkat pembelajaran matematika yang dikembangkan. Kategori efektif menurut Trianto (2010) adalah jika kemampuan pemahaman konsep siswa mencapai KKM yang ditetapkan sekolah. Hasil pengolahan data kemampuan pemahaman konsep dapat dilihat pada Tabel 5 .

Tabel 5. Data hasil tes kemampuan pemahaman konsep

\begin{tabular}{cc}
\hline Komponen & Nilai \\
\hline Sampel & 28 \\
Nilai tertinggi & 95 \\
Nilai terendah & 65 \\
Rata-rata & 83,60 \\
Varians & 77,80 \\
Standar deviasi & 8,82 \\
\hline
\end{tabular}

Berdasarkan data pada tabel 5 diketahui bahwa perangkat pembelajaran seperti RPP, LKS dan Modul berorientasi REACT dan STEM yang dikembangkan memenuhi aspek keefektifan dilihat dari hasil tes kemampuan pemahaman konsep siswa. Hal ini menunjukkan bahwa perangkat pembelajaran yang dikembangkan valid, praktis dan efektif serta layak untuk dipakai. Selain itu, kemampuan pemahaman konsep siswa dapat berkembang dengan baik, karena pada LKS yang dikembangkan terdapat langkah-langkah kerja yang harus dilakukan oleh siswa dalam menemukan suatu teori atau konsep. Latihan yang diberikan juga dapat membuat kemampuan pemahaman konsep siswa berkembang.

Perangkat pembelajaran ini dapat membantu guru melatih kemampuan pemahaman konsep siswa. Hal ini disebabkan penggunaan media dan perangkat pembelajaran yang sesuai dengan kebutuhan siswa seperti LKS dan modul yang telah dikembangkan. Sejalan dengan pendapat (Zahro, Serevina, \& Astra, 2017) yang mengatakan bahwa media pembelajaran merupakan salah satu alat yang dapat membantu guru menyampaikan materi pembelajaran dan menjadi faktor penentu keberhasilan pembelajaran. Ibrahim \& Yusuf (2019) juga mengatakan bahwa, penggunaan metoda, media dan sumber pembelajaran yang menyenangkan, sesuai dengan karakteristik siswa serta disusun secara sistematis dengan menggunakan bahasa yang mudah dipahami oleh siswa dapat meningkatkan minat dan motivasi mereka untuk belajar, sehingga tujuan pembelajaran dapat tercapai.

Selain itu, pembelajaran yang menerapkan strategi REACT dalam prosesnya dapat mempengaruhi pemahaman konsep siswa terhadap materi yang diberikan. Hal ini disebabkan karena dalam strategi REACT siswa dituntut untuk dapat merekonstruksi sendiri materi/konsep pembelajaran dengan bekerjasama dalam kelompok dan mentransfer konsep yang telah mereka dapatkan sebelumnya dalam konteks materi yang baru (Rahmadhani \& Wahyuni, 2018). Tidak hanya melalui strategi REACT, pengintegrasian STEM dalam proses pembelajaran terutama dalam perangkat pembelajaran dapat memberikan efek yang positif terhadap hasil belajar siswa. Karena siswa tidak hanya diberikan konsep materi saja tetapi mereka juga diberikan kesempatan untuk melakukan praktek langsung yang dapat melatih kemampuan kognitif siswa, keterampilan dan afektif mereka dalam pembelajaran (Septiani, 2016, \& Becker \& Park, 2011). Hal ini sejalan 
dengan pendapat beberapa peneliti yang mengatakan bahwa penggunaan STEM dalam pembelajaran tidak hanya dapat meningkatkan prestasi akademik siswa saja, tetapi juga bisa membantu meningkatkan kemampuan menguasai konsep, mengaplikasikan kosep yang mereka dapatkan dalam memecahkan masalah serta membantu mereka untuk lebih kreatif dalam menciptakan sesuatu hal yang baru (Permanasari, 2016).

Dari hasil penelitian ini diperoleh perangkat pembelajaran berupa RPP, LKS dan modul berorientasi REACT dan STEM yang layak untuk digunakan dalam melihat kemampuan pemahaman konsep siswa terutama pada materi Bangun Datar. Diharapkan dengan dikembangkannya perangkat pembelajaran ini dapat membantu guru membimbing siswa mencapai tujuan dari pembelajaran terutama mempersiapkan mereka menghadapi tantangan era pendidikan yang semakin maju sekarang ini. Dalam penggunaan perangkat pembelajaran ini ada beberapa hal yang perlu menjadi perhatian oleh guru, diantaranya adalah manajemen waktu. Guru diharapkan dapat mengatur waktu sebaik mungkin ketika menggunakan LKS dan modul yang dikembangkan, apalagi pada pertemuan pertama. Pada pertemuan pertama tersebut biasanya siswa mengalami kesulitan dalam menggunakan perangkat yang kita berikan karena mereka tidak terbiasa dengan media tersebut sebelumnya.

\section{KESIMPULAN DAN SARAN}

Pada penelitian pengembangan ini, produk yang dikembangkan berupa Rencana Pelaksanaan Pembelajaran (RPP), Lembar Kerja Siswa (LKS) dan modul yang berorientasi strategi REACT dan STEM untuk melihat kemampuan pemahaman konsep siswa.
Berdasarkan pengolahan data dan analisis yang telah dilakukan sebelumnya, diperoleh kesimpulan bahwa: perangkat pembelajaran yang dikembangkan berupa RPP, LKS dan Modul dapat dikategorikan valid berdasarkan hasil validasi ahli pendidikan matematika, model pembelajaran dan ahli media pembelajaran. Perangkat tersebut juga dapat dikatakan praktis untuk digunakan. Terlihat dari data kemampuan guru mengelola pembelajaran dengan menggunakan perangkat yang dikembangkan dengan kriteria sangat baik. Respon guru terhadap perangkat yang digunakan memiliki kriteria sangat praktis sedangkan respon siswa terhadap pembelajaran sangat baik. Selain itu, berdasarkan hasil pengolahan data efektifitas, perangkat pembelajaran yang dikembangkan efektif untuk digunakan, terlihat dari rata-rata tes kemampuan pemahaman konsep siswa Hal ini menunjukkan bahwa perangkat pembelajaran berorientasi REACT dan STEM layak untuk digunakan dalam melihat kemampuan pemahaman konsep siswa.

Untuk penelitian selanjutnya diharapkan dapat mengembangkan perangkat dengan materi lainnya dalam membantu mengembangkan kemampuan pemahaman konsep siswa.

\section{DAFTAR PUSTAKA}

Afriana, J., Permanasari, A., \& Fitriani, A. (2016). Penerapan Project Based Learning Terintegrasi STEM Untuk Meningkatkan Literasi Sains Siswa Ditinjau Dari Gender. Jurnal Inovasi Pendidikan IPA, 2(2), 202-212. https://doi.org/10.21831/jipi.v2i2.85 61

Becker, K., \& Park, K. (2011). Effects of Integrative Approaches Among Science, Technology, Engineering, 
DOI: https://doi.org/10.24127/ajpm.v10i2.2986

and Mathematics (STEM) Subjects on Students Learning: A Preliminary Meta-Analysis. Journal of STEM Education, 12(5 \& 6), 2337.

Crawford, LM. 2001. Teaching Contextually: Research, Rational and Technique for Imploving Student Motivation and Achievement in Mathematics Science. Texas: CCI Publishing, INC

Depdiknas. 2013. Peraturan Menteri Pendidikan Nasional Nomor 65 Tahun 2013 tentang Standar Proses Pendidikan Dasar dan Menengah. Jakarta: Badan Standar Nasional Pendidikan.

Hobri. 2010. Metodologi Penelitian Pengembangan (Aplikasi Pada Penelitian Matematik). Jember: Pena Salsabila

Ibrahim, E., \& Yusuf, M. (2019). Implementasi Modul Pembelajaran Fisika dengan Menggunakan Model React Berbasis Kontekstual Pada Konsep Usaha dan Energi. Jambura Physics Journal, 1(1), 1-13. https://doi.org/10.34312/jpj.v1i1.228 1

Jannah, M. M., Supriadi, N., \& Suri, F. I. (2019). Efektivitas Model Pembelajaran Visualization Auditory Kinesthetic (VAK) Terhadap Pemahaman Konsep Matematis Berdasarkan Klasifikasi Self-Efficacy. AKSIOMA: Jurnal Program Studi Pendidikan Matematika, 8(1), 215-224. https://doi.org/https://doi.org/10.241 27/ajpm.v8i1.1892

Kamarullah. (2017). Pendidikan Matematika Di Sekolah Kita. Al Khawarizmi: Jurnal Pendidikan Dan Pembelajaran Matematika, 1(1), 2132.

Kusumaningsih, W., Sutrisno, \& Hidayah, F. (2019). Efektivitas Model Pembelajaran SAVI dan
REACT Berbantuan LKS terhadap Kemampuan Komunikasi Matematis Siswa SMP. Journal of Medives: Journal of Mathematics Education IKIP Veteran Semarang, 3(2), 197206.

Lestari, M., Lestari, P. B., \& Ridha, M. R. (2018). Penerapan Metode Personalized System of Instruction Untuk Meningkatkan Kemampuan Pemahaman Konsep Matematis. Intermathzo Jurnal Pendidikan Dan Pembelajaran Matematika, 3(2), 132-139.

National Research Council. 2011. A Framework for K-12 Science Education: Practice, Crosscutting Concepts and CORE Ideas. Washington DC: The National Academies Press

NCTM. 2000. Principles and Standards for School Mathematics. Reston VA: Authur

Nessa, W., Hartono, Y., \& Hiltrimartin, C. (2017). Pengembangan Buku Siswa Materi Jarak Pada Ruang Dimensi Tiga Berbasis Science, Technology, Engineering, and Mathematics (STEM) ProblemBased Learning Di Kelas X. Jurnal Elemen, 3(1), 1-14.

Nugroho, E. S. B., Prayitno, B. A., \& Maridi. (2017). Pengembangan Modul Berbasis REACT Pada Materi Jamur Untuk Meningkatkan Kemampuan Berpikir Kritis Siswa Kelas X SMA. Didaktika Biologi: Jurnal Penelitian Pendidikan Biologi (2017), 1(1), 1-10.

Prayitno, Edi. 2003. Pedoman Pengembangan Sistem Penilaian. Yogyakarta: FMIPA UNY \& Dirjen PLP Depdiknas

Permanasari, A. (2016). STEM Education: Inovasi dalam Pembelajaran Sains. SEMINAR NASIONAL PENDIDIKAN SAINS "Peningkatan Kualitas Pembelajaran Sains Dan 
DOI: https://doi.org/10.24127/ajpm.v10i2.2986

Kompetensi Guru Melalui Penelitian \& Pengembangan Dalam Menghadapi Tantangan Abad-21," 23-34. Surabaya.

Prihatiningtyas, N. C., \& Mariyam. (2019). Model Student Facilitator and Explaining Terhadap Kemampuan Pemahaman Konsep Matematis. AKSIOMA: Jurnal Program Studi Pendidikan Matematika, 8(3), 465-473. https://doi.org/https://doi.org/10.241 27/ajpm.v8i3.2365

Purbasari, R. julia, Kahfi, M. S., \& Yunus, M. (2013). Pengembangan Aplikasi Android Sebagai Media Pembelajaran Matematika Pada Materi Dimensi Tiga Untuk Siswa SMA Kelas X. Jurnal Online Universitas Negeri Malang, 1-11. Retrieved http://lib.unnes.ac.id/3749/

Rahmadhani, E.-. (2017). Peningkatan Kemampuan Komunikasi Matematis Siswa SD Kelas V Melalui Pembelajaran Dengan Strategi REACT. Eduma: Mathematics Education Learning and Teaching, 6(1), 14-22. https://doi.org/10.24235/eduma.v6i1 .1415

Rahmadhani, E. (2016). Peningkatan Pemahaman Konsep Siswa SD Melalui Pembelajaran dengan Menggunakan Strategi REACT. THEOREMS, 1(1), 9-18.

Rahmadhani, E., \& Wahyuni, S. (2018). Kemampuan Pemahaman Konsep Dan Minat Mahasiswa dengan Pendekatan STEM (Science, Technology, Enginnering, Mathematics). Seminar Nasional Pendidikan Matematika 2018, 01, 129-140. Jakarta: UHAMKA.

Romadon, S., \& Mahmudi, A. (2019). Penerapan Pendekatan Penemuan Terbimbing Untuk Meningkatkan Kemampuan Pemahaman Konsep Matematis Siswa. AKSIOMA: Jurnal Program Studi Pendidikan
Matematika, $\quad 8(1), \quad$ 58-64. https://doi.org/https://doi.org/10.241 27/ajpm.v8i1.1684

Septiani, A. (2016). Penerapan Asesmen Kinerja dalam Pendekatan Stem (Sains Teknologi Engineering Matematika) Untuk Mengungkap Keterampilan Proses Sains. Seminar Nasional Pendidikan Dan Saintek 2016, 654-659. Bandung: Universitas Pendidikan Indonesia.

Trianto. 2010. Mendesain Model Pembelajaran Inovatif Progresif. Jakarta: Kharisma Putra Utama

Utami, T. N., \& Jatmiko, A. (2018). Pengembangan Modul Matematika dengan Pendekatan Science, Technology, Engineering, And Mathematics (STEM) pada Materi Segiempat. 1(2), 165-172.

Wardhani, S. 2010. Teknik Pengembangan Instrumen Penelitian Hasil Belajar Matematika di SMP/MTs. Yogyakarta: Pusat Pengembangan dan Pemberdayaan Pendidik dan Tenaga Kependidikan (PPPPTK) Matematika

Wijaya, A. P., Yunarti, T., \& Ludinsyah, J. (2019). Efektivitas Pembelajaran Preview, Question, Read, Reflect, Recite, Review Ditinjau dari Pemahaman Konsep Matematis. AKSIOMA: Jurnal Program Studi Pendidikan Matematika, 8(2), 333343. https://doi.org/https://doi.org/10.241 27/ajpm.v8i2.2128

Zahro, U. L., Serevina, V., \& Astra, M. (2017). Pengembangan Lembar Kerja Siswa (Lks) Fisika dengan Menggunakan Strategi Relating, Experiencing, Applying, Cooperating, Transferring (React) Berbasis Karakter Pada Pokok Bahasan Hukum Newton. WaPFi (Wahana Pendidikan Fisika), 2(1), 4-9. https://doi.org/10.17509/wapfi.v2i1. 4906 